TABLE 1. Surgical procedures

\begin{tabular}{lcll}
\hline Associated procedures & No. & Mitral repair procedures & No. \\
\hline CABG & 3 & Resection of posterior leaflet & 4 \\
TVR & 1 & Resection of anterior leaflet & 1 \\
& & PTFE chordae implantation* & 3 \\
& & Papillary muscle shortening & 2 \\
\hline \hline
\end{tabular}

Preoperative and postoperative echochardiographic parameters

\begin{tabular}{lccc}
\hline Characteristics & Preoperative & Postoperative & 1-yr follow-up \\
\hline LA $(\mathrm{mm})$ & $55.4 \pm 6.8$ & $49.2 \pm 5.4$ & $41.4 \pm 6.2 \dagger$ \\
LVED $(\mathrm{mm})$ & $65.2 \pm 5.1$ & $60.8 \pm 5.5$ & $51.2 \pm 7.3 \dagger$ \\
LVES $(\mathrm{mm})$ & $43.5 \pm 3.9$ & $41.2 \pm 6.1$ & $36.1 \pm 8.4$
\end{tabular}

$C A B G$, Coronary artery bypass graft; TVR, tricuspid valve repair; $L A$, left atrial; $L V E D$, left ventricular end-diastolic; $L V E S$, left ventricular end-systolic; PTFE, polytetrafluoroethylene.

*Chordal replacement with a 4.0 PTFE suture.

$\dagger$ Values differ significantly from preoperative values $(P<.1)(t$ test for paired samples and Wilcoxon matched-pairs signed-ranks test).

\section{References}

1. Khargi K, Deneke T, Haardt H, Lemke B, Grewe P, Müller KM, et al. Saline-irrigated, cooled-tip radiofrequency ablation is an effective technique to perform the maze procedure. Ann Thorac Surg. 2001;72: S1090-5.

2. Schuetz A, Schulze C, Sarvanakis K, Mair H, Plazer H, Kilger E, et al. Surgical treatment of permanent atrial fibrillation using microwave energy ablation: a prospective and randomized clinical trial. Eur J Cardiothorac Surg. 2003;24:475-80.

3. Gillinov M, Peterson G, Rice TH. Esophageal injury during radiofre- quency ablation for atrial fibrillation. $J$ Thorac Cardiovasc Surg. 2001;122:1239-40.

4. Mohr F, Fabricius A, Falk V, Autschbach R, Doll N, von Oppel U, et al. Curative treatment of atrial fibrillation with intraoperative radiofrequency ablation: short term and midterm results. $J$ Thorac Cardiovasc Surg. 2002;123:919-27.

5. Sie H, Beukema W, Misier A, Elvan A, Ennema J, Wellens H. The radiofrequency modified maze procedure. A less invasive surgical approach to atrial fibrillation during open-heart surgery. Eur J Cardiothorac Surg. 2001;19:443-7.

\title{
Inhaled nitric oxide does not improve systemic oxygenation after bidirectional superior cavopulmonary anastomosis
}

Ian Adatia, MBChB, ${ }^{a, b}$ Andrew M. Atz, MD, ${ }^{a}$ and David L. Wessel, MD, ${ }^{a}$ Boston, Mass, and Toronto, Ontario, Canada

$\mathrm{I}$ nhaled nitric oxide (NO) is a selective pulmonary vasodilator that decreases intrapulmonary shunt fraction. ${ }^{1}$ We sought to determine whether inhaled $\mathrm{NO}$ would ameliorate hypoxemia after bidirectional superior cavopulmonary anastomosis (BCPA).

\footnotetext{
From the Department of Cardiology, Children's Hospital, and Departmen of Pediatrics, Harvard Medical School, ${ }^{\text {a }}$ Boston, Mass, and Department of Critical Care Medicine and Division of Cardiology, Hospital for Sick Children Toronto, ${ }^{\mathrm{b}}$ Toronto, Ontario, Canada.

Received for publication April 5, 2004; accepted for publication April 13, 2004.

Address for reprints: Ian Adatia, MBChB, University of California at San Francisco Children's Hospital, 505 Parnassus Ave, Room M-655, San Francisco, CA 94143-0106 (E-mail: iadatia@ @edcard.ucsf.edu).

J Thorac Cardiovasc Surg 2005;129:217-9

$0022-5223 / \$ 30.00$

Copyright $\odot 2005$ by The American Association for Thoracic Surgery doi:10.1016/j.jtcvs.2004.04.024
}

\section{Methods}

The research and ethics review board approved the study, and the parents of all children gave informed and written consent. We included patients with systemic oxygen saturations of $75 \%$ or less after BCPA without venous decompressing collaterals or pulmonary disease. Patients were mechanically ventilated and studied on the first postoperative day in the intensive care unit. From a stable baseline, patients received a 15-minute trial of inhaled NO (80 $\mathrm{ppm}){ }^{2}$ During the trial of inhaled NO, ventilator parameters and $\mathrm{FIO}_{2}$ were unchanged. In 5 patients, cyclic guanosine monophosphate (cGMP) levels were measured. ${ }^{2}$ One patient first received inhaled NO in the cardiac catheterization laboratory because of persistent hypoxemia after coil embolization of decompressing venous collaterals. This same patient was readmitted 7 months after BCPA with refractory hypoxemia as the result of respiratory syncytial viral pneumonitis and was treated with $10 \mathrm{ppm}$ NO.

\section{Statistical Analysis}

A paired Student $t$ test with a Bonferroni correction for 3 comparisons was used. The difference between cGMP levels was compared by the nonparametric Wilcoxon signed-rank test. 
TABLE 1. Hemodynamic and blood gas response to inhaled nitric oxide after bidirectional superior cavopulmonary anastomosis (mean $\mathrm{FiO}_{2} \mathrm{O} .76 \pm 0.2$ )

\begin{tabular}{|c|c|c|c|c|c|c|c|c|c|c|}
\hline & $\begin{array}{c}\text { Mean } \\
\text { SVCp } \\
\text { (mm Hg) }\end{array}$ & $\begin{array}{c}\text { Mean CAp } \\
(\mathrm{mm} \mathrm{Hg})\end{array}$ & $\begin{array}{c}\text { TPG } \\
(\mathrm{mm} \mathrm{Hg})\end{array}$ & $\begin{array}{c}\text { Mean BP } \\
(\mathrm{mm} \mathrm{Hg})\end{array}$ & $\begin{array}{c}\text { SVC sat } \\
(\%)\end{array}$ & $\begin{array}{c}\text { Art sat } \\
(\%)\end{array}$ & $\begin{array}{l}\text { Art } \mathrm{PaO}_{2} \\
(\mathrm{~mm} \mathrm{Hg})\end{array}$ & $\begin{array}{c}\text { Art } \mathrm{PaCO}_{2} \\
(\mathrm{~mm} \mathrm{Hg})\end{array}$ & Art pH & $\begin{array}{c}\text { HR } \\
\text { (beats/min) }\end{array}$ \\
\hline Pre-NO & $17 \pm 3$ & $7 \pm 2$ & $9 \pm 5$ & $65 \pm 11$ & $33 \pm 11$ & $63 \pm 7$ & $32 \pm 4$ & $38 \pm 9$ & $7.46 \pm 0.08$ & $143 \pm 21$ \\
\hline With NO & $15 \pm 3^{*}$ & $7 \pm 2$ & $7 \pm 5$ & $62 \pm 9$ & $34 \pm 12$ & $65 \pm 5$ & $32 \pm 4$ & $38 \pm 8$ & $7.46 \pm 0.07$ & $146 \pm 20$ \\
\hline Post-NO & $16 \pm 3 \dagger$ & $8 \pm 2$ & $8 \pm 4$ & $63 \pm 12$ & $31 \pm 7$ & $64 \pm 7$ & $32 \pm 4$ & $38 \pm 8$ & $7.46 \pm 0.06$ & $146 \pm 18$ \\
\hline
\end{tabular}

Art, Systemic arterial; $B P$, blood pressure; $C A p$, common atrial pressure; $H R$, heart rate; $N O$, nitric oxide; $S V C$, superior vena cava; $S V C p$, superior vena cava pressure; $T P G$, transpulmonary gradient. Values are mean $\pm \mathrm{SD}$.

$* P=.002$ compared with pre-NO.

$\dagger P=.013$ compared with pre-NO.

TABLE 2. Cyclic guanosine monophosphate levels in response to inhaled nitric oxide after bidirectional superior cavopulmonary anastomosis

\begin{tabular}{lcr}
\hline & $\begin{array}{c}\text { SVC pmol/mL, } \\
\text { median (range) }\end{array}$ & $\begin{array}{r}\text { Artery pmol/mL, } \\
\text { median (range) }\end{array}$ \\
\hline Pre-NO & $11.2(9.4-14.0)$ & $9.7(9.2-13.2)$ \\
With NO & $51.8(30-124)^{*}$ & $54.8(36-128)^{*}$ \\
\hline
\end{tabular}

$S V C$, Superior vena cava; $N O$, nitric oxide.

$* P=.04$ pre-NO versus with NO.

\section{Results}

We studied 26 patients with a median age of 0.5 years (range $0.2-13$ years) and a weight of $6.5 \mathrm{~kg}$ (range $3-41 \mathrm{~kg}$ ) who had undergone BCPA. All patients were undergoing the second stage of cardiac palliation for a functionally single ventricle. The diagnoses were hypoplastic left heart syndrome in 19 patients, tricuspid atresia with transposed great arteries with aortic obstruction in 3 patients, unbalanced atrioventricular canal defects in 2 patients, Ebstein anomaly of the tricuspid valve in 1 patient, and doubleinlet left ventricle in 1 patient.

The results of the trial of inhaled NO are displayed in Tables 1 and 2. There was no change in systemic oxygenation in response to inhaled NO. However, there was a significant decrease in superior vena caval pressure. Plasma cGMP increased significantly.

One patient received a trial of inhaled NO during cardiac catheterization to coil decompressing venous collaterals. After deployment of coils, the aortic oxygen saturation increased from $50 \%$ to $62 \%$ with an $\mathrm{FiO}_{2}$ of 1.0. Inhaled $\mathrm{NO}$ changed aortic saturation minimally from $62 \%$ to $64 \%$. Superior vena caval mean pressure decreased from 16 to $14 \mathrm{~mm} \mathrm{Hg}$. Pulmonary vein oxygen saturation and oxygen tension increased from $97 \%$ to $99 \%$ and 94 to $260 \mathrm{~mm} \mathrm{Hg}$, respectively. This patient was readmitted with respiratory syncytial viral pneumonitis, hypoxemia, and facial edema without cavopulmonary obstruction. The inhaled NO was administered at $10 \mathrm{ppm}$, systemic oxygen saturations increased from $48 \%$ to $87 \%$, and transpulmonary gradient decreased from 12 to $4 \mathrm{~mm} \mathrm{Hg}$. Treatment was continued for 93 hours with gradual resolution of pneumonia.

The mean hemoglobin concentration was $13.9 \pm 2 \mathrm{~g} / \mathrm{dL}$, and the methemoglobin concentration was $0.6 \pm 1.4 \mathrm{~g} / \mathrm{dL}$. Nitrogen dioxide levels ranged from less than 1 to $4 \mathrm{ppm}$.

\section{Discussion}

We found that inhaled NO does not improve systemic oxygenation after BCPA in the absence of intrapulmonary shunting. The decrease in superior vena caval pressure and increase in plasma cGMP indicate that sufficient NO was delivered to activate guanylate cyclase and cause vasodilation. This suggests that pulmonary vasoconstriction does not limit pulmonary blood flow or determine systemic oxygen saturations after BCPA. In 1 patient with pulmonary venous desaturation, inhaled NO enhanced ventilation perfusion matching with substantial improvement in oxygenation. Previous studies of the effect of inhaled NO after BCPA are equivocal. In 4 patients, oxygenation deteriorated when $\mathrm{NO}$ was withdrawn, and 5 patients demonstrated a $5 \%$ increase in systemic oxygen saturation. ${ }^{3,4}$ Clinical details are insufficient to determine whether these patients had pulmonary venous desaturation. ${ }^{3,4}$ In contrast, we showed in 26 patients that inhaled NO does not improve systemic oxygenation in the absence of pulmonary venous desaturation after BCPA. These observations suggest that cardiac output and cerebral blood flow after BCPA are more important determinants of oxygenation than pulmonary vascular resistance. Indeed, recent studies demonstrated that a strategy of permissive hypercapnia improves oxygenation after BCPA. ${ }^{5,6}$ Although we report a "negative study," it has important implications both for the additional insight provided into the unique physiology of BCPA and the therapeutic economics. Inhaled NO has been transformed from an inexpensive medical grade gas to a costly pharmaceutical grade gas. Therefore, the use of inhaled NO should be justified fiscally and therapeutically. Our study suggests that after BCPA, strategies that increase cardiac output and cerebral blood flow (eg, hypercapnia) are more likely to improve oxygenation than inhaled NO unless there is concomitant pulmonary venous desaturation.

\section{References}

1. Adatia I, Lillehei C, Arnold JH, Thompson JE, Palazzo R, Fackler JC, et al. Inhaled nitric oxide in the treatment of postoperative graft dysfunction after lung transplantation. Ann Thorac Surg. 1994;57: 1311-18.

2. Wessel DL, Adatia I, Giglia TM, Thompson JE, Kulik TJ. Use of inhaled nitric oxide and acetylcholine in the evaluation of pulmonary hypertension and endothelial function after cardiopulmonary bypass. Circulation. 1993;88(part 1):2128-38. 
3. Gamillscheg A, Zobel G, Urlesberger B, Berger J, Dacar D, Stein JI, et al. Inhaled nitric oxide in patients with critical pulmonary perfusion after Fontan-type procedures and bidirectional Glenn anastomosis. J Thorac Cardiovasc Surg. 1997;113:435-42.

4. Yahagi N, Kumon K, Tanigami H, Watanabe Y, Haruna M, Hayashi H, et al. Cardiac surgery and inhaled nitric oxide: indication and follow-up (2-4 years). Artif Organs. 1998;22:886-91.
5. Bradley SM, Simsic JM, Mulvihill DM. Hypoventilation improves oxygenation after bidirectional superior cavopulmonary connection. J Thorac Cardiovasc Surg. 2003;126:1033-39.

6. Hoskote A, Li J, Hickey C, Erickson S, vanArsdell G, Stephens D, et al. The effects of carbon dioxide on oxygenation, systemic, cerebral and pulmonary vascular hemodynamics after the bidirectional superior cavopulmonary anastomosis. J Am Coll Cardiol. In press.

\section{Bonanno's catheter: A less invasive and cost- effective alternative for drainage of pleural effusion}

\section{Govind K. Chetty, FRCS, Maqsood M. Elahi, MRCS, Vishwanath Siddagangaiah, MBBS, and Joseph N. Leverment, FRCS, Leicester, United Kingdom}

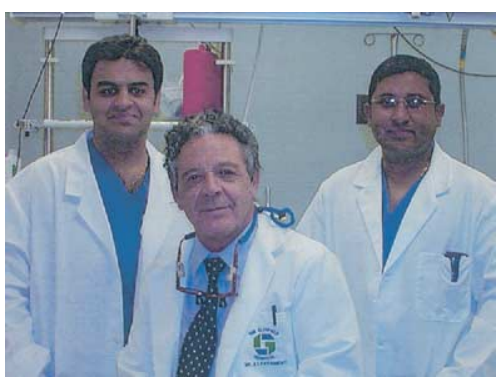

Elahi, Leverment, Chetty (left to right)

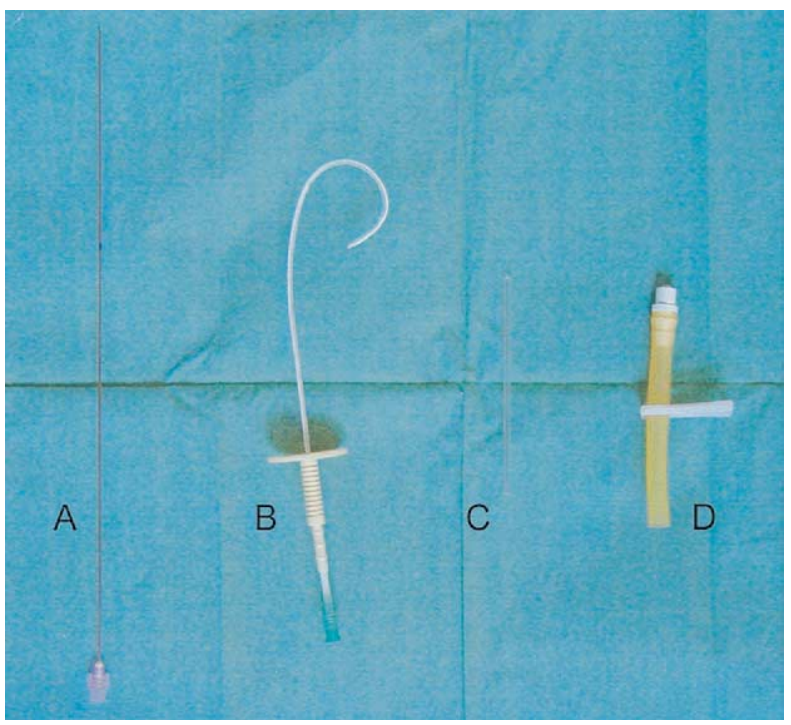

Figure 1. Bonanno's catheter and syringe.

(Figure 1). A 3- to 4-mm incision is made in the skin to avoid damage to the catheter tip, and the catheter is inserted gradually while applying constant suction on the syringe. As soon as serous fluid is aspirated, the trocar is held in a static position while advancing the cannula into the pleural cavity. The trocar is removed, and serous fluid should flow freely from the catheter, which can now be attached with the rubber tubing to a conventional underwater drainage system. The catheter is sutured to the skin, and a chest radiograph will confirm the position of the catheter (Figures 2 and 3).

\section{Conclusion}

Apart from standard tube thoracostomy, which can be quite invasive and painful, ${ }^{2}$ patients with pleural effusion could also undergo 